\title{
ADMINISTERING CLASSES IN VIRTUAL LEARNING ENVIRONMENT: FACILITATIONS, PRINCIPLES, EDUCATORS' ROLES AND INTERACTIONS
}

\author{
Nur Afni Mahiya Usemahu \\ Tarbiyah and Teachers' Training Faculty, Antasari State Islamic University \\ afniya329@gmail.com \\ Yulia Fernandita \\ Tarbiyah and Teachers' Training Faculty, Antasari State Islamic University \\ fernandita.yulia@gmail.com
}

\begin{abstract}
This study investigates teachers' competencies in the implementation of facilities, principles, educators' roles, and interactions in the Virtual Learning Environment (VLE). Using explanatory sequential mixed method, it aims to examine whether all those competencies such as learning system tools and resources, technology quality, and workload management are considered throughout the learning process. In total, 102 students from the Faculty of Tarbiyah and Teachers' Training at Antasari State Islamic University were involved in the survey. Fourteen of them, as well as three lecturers, were then interviewed. The results indicate that despite students' limited access to the internet, lecturers attempt to provide all students' facilities. However, in some departments, various learning activities, monitoring, and feedback still need to be improved. The lecturers generally execute the principle of the virtual learning environment. The students mostly believe that lecturers are aware of their roles, and manage their interactions well. In conclusion, the study suggests teachers' competencies in the virtual learning environment and calls for further studies in this subject.
\end{abstract}

Keywords: Virtual Learning Environment; facilities; principles; educator's roles; interaction

\section{A. INTRODUCTION}

$\mathrm{I}$

n 2020, the urgency of internet use as a communication tool had dramatically increased. Since COVID-19 pandemic hit more than 200 countries globally. General society were required to remain indoors and do everything from home. That the virus transmitted very fast also demanded everyone including learning communities to adapt and continue the learning and teaching process via internet platforms. Even though it is much efficient in space and time, Virtual Learning Environment (VLE) still has significant limitations comparing to traditional classroom. In the case of this pandemic times when most learning communities in Indonesia tend to lack preparation, it is crucial for online class administrations to have an in-depth investigation. Therefore, this prospective study is designed to observe whether the mechanism of VLE still provides sufficient qualities of class administration.

Numerous ELT studies are discussing these online teaching and learning implementation. However, studies conducted in Indonesia that observe class 
administration with the context of COVID-19 pandemic are still limited. The few related research is EFL Classes Must Go Online! Teaching Activities and Challenges during COVID-19 Pandemic in Indonesia by Nugroho \& Atmojo (2020). With data obtained from 16 secondary school teachers teaching in 11 different cities, the study shows that the online learning process did not run smoothly due to a lack of planning and preparation. However, this study has only focused on teaching activities and challenges from teachers' perspective, while class administration of VLE covers a lot more to observe.

The next related study is Online Learning and Its Problems in The COVID-19 Period by Rimba Hamid, et al in 2020. With participants consisting of 316 students of the Primary School Teacher Education Department at Halu Oleo University, this study points out that students' dissatisfaction with online learning is relatively high $(58.4 \%)$ due to similar cause with the previously mentioned study: lack of preparation. Then it is mentioned that internet access and device capability are the main tools to experience an effective VLE and according to the students', the implementation has not been fully effective. This research has shown students' struggles in VLE in general. However, we need to recognize which VLE aspects in detail to improve so that we could ensure better VLE implementation in the future.

In the same vein, Destianingsih and Satria (2020) in their study entitled Investigating Students Needs for Effective English Online Learning During COVID-19 for Polbeng Students note students' needs for suitable learning platforms, learning activities for students' language proficiency and some lacking teachers' roles in managing VLE. With 116 participants, the study utilizes questionnaire to collect the data, whereas this research integrates qualitative and quantitative data collection. Another significant difference is this previous study observes students' needs and wants to focus on each English skills, while the objective of our research is to explore the implemented class administration qualities based on scientific theories. In addition, there is still very little number of research found that surveyed comprehensive administration of VLE in the context of COVID-19 pandemic in Indonesia.

Thus, in the pages that follow, it will examine the quality of four important aspects of administering classes in VLE: facilitation, principles, educators' roles and interactions. With the explanatory sequential mixed method, it will attempt to represent the reality as close as possible. The result is expected to contribute to higher performance for online learning communities especially in Indonesia as well as providing useful insights for further studies. 
Usemahu, Fernandita, Administering Classes in Virtual Learning Environment...

\section{B. LITERATURE REVIEW}

\section{Facilities for E-Learning}

Below is a list of e-learning facilitation according to Teaching Online is Different by Ní Shé, C.et al. (2019).

a) Organizing Course Structure and Consistency

Severalstudies have emphasized how vital the need for course structure and determined approaches to content design. To provide learning facilities, staff/teachers must complete the course design which requires arranging weekly topics or tasks, chunking contentaccessible for students and providingthe students clear signposting. Consistency is also essential in the course organization to put the learners at ease to track down their steps during the course.

b) Starting an Online Course

In this facilitation, educators must make it clear that students' participation, their level of contributions, interactions anddeadlines are highly valued. Considering a wellplannedicebreaker activities, presenting an introductory video, interaction in theearly start of discussions are paths to gain good results (Coker, 2018; Peacock \& Cowan, 2019). Try to strictly follow the divisional guidelines for schedule. A timetable designed with thorough consideration would likely result in a natural flow of learning experience for the students. (Shanghai American School, 2020).

c) Facilitating Discussions

Berge (1995) explained one of the most crucial facilitation of online educators to perform iseffective teaching. Following this, he then quoted Rohfeld \& Hiemstra (1995) that it is the duty to keep the discussions' progress going, add supporting insights, construct the students' discussion thread and course components, and create harmony in discussions. A model proposed by Coker (2018) to lead how online teachers should facilitate online discussions with three foci: knowledge, affect, and dialogue.

In technically facilitating online discussions, Shanghai American School (2020) proposed that educators are advised to consider the size of the files to be downloaded by students. Electronic copy of references for the course may enable the teacher to remotely distribute materials for the learners' device. Teachers have to recognize that not all students have limitless internet connection. To address this issue, the size matters to ensure that nobody is left behind.

d) Feedback for Students

According to Abdous (2011) and Corfman and Beck (2019) feedback quality should 


\section{Volume 7, Number 01, June 2021}

cover constructive criticism, encouragement, fixing misconceptions and give further information. Berge (2008) stated automation allows advanced ways of providing feedback to learners. Providing feedback through video and audio is considered transformative and effective for a successful assessment in online discussion forums (Boruv \& Evmenova, 2019; Peacock \& Cowan, 2019). An automatic system on online quizzes with repeat opportunity is also another effective way for students to easily diagnose their mistakes (Meyer \& McNeal, 2011).

Some guidelines are given by Shanghai American School (2020) to encourage teachers in providing effective feedback is with timely feedback to student learning, clear communication, actively checking email for communications; avoiding, unless planned and limited, real-time chats.

e) Content and Context

The urgency of content knowledge alongside giving real examples in learning process has been highlighted by many professional online educators such as Coker (2018) and Meyer \& McNeal (2011). Designing courses also means considering student's contexts including the status of their degree: undergraduate/postgraduate student; studying hours: part time/full time; their background: international/domestic student (Martin, 2019).

f) Reflection

Dewey stated that reflection plays a big role in teaching experiences integration in both practical theories. Speaking about reflection, Baran et al. (2011) and Meyer (2013) have recommended it to be critical on both online teacher's changing roles and competencies. To support students' metacognition, as students progress through the course, they should be encouraged heir online teachers to reflect on their studies.

g) Learning Activities

Educators can insert experiential learning, real world experiences and online scenarios (Gómez-Rey et al., 2018; Martin et al., 2019; Meyer \& McNeal, 2011; Shattuck et al., 2011; Trammell \& LaForge, 2017). Martin et al. (2019) explained that successful faculty will highlight learning activities alongside the assessment. Gómez-Rey et al. (2018) discussed the selection of media, platforms and tools that will be implemented also determine the effectiveness of the learning process.

Consider varying the activities step by step, from highly different to slightly modified activities (Shanghai American School, 2020). Students have different interests, experiences and learning styles ensuring the lessons appeal to them is crucial to obtain 
Usemahu, Fernandita, Administering Classes in Virtual Learning Environment...

the optimal progress. Another recommendation is to include offline activities. Try to create lively online learning by offering some opportunities for reading, research, online discussions and journaling (American Shanghai School, 2020).

h) Designing Collaboration and Groupwork

Coker (2018) mentioned that it is necessary to consider designing group work for online learning. Since VLE is quite different from traditional classroom, Gómez-Rey et al. (2018) and Trammell \& LaForge (2017) mentioned that larger groups than usual needed to be designed since absence would bring a bigger impact on the online learning process. Bear in mind to keep online learning tasks simple and directions clear (Shanghai American School, 2020). Collaborative activities have been highlighted to develop students' interaction so that their social presence will let them share perspectives.

\section{Principles of E-Learning}

According to Clark and Mayer (2008), there are principles teachers should probably apply to create psychological-learning-friendly course:

a) Multimedia Principle

Cognitive processing may need to be stimulated to attract learners. This process involves comprehension, organization, and integration of materials they are given. By employing multimedia presentation, teacher can probably encourage students to engage themselves actively. By mentally processing content along with coherent pictures may help to get their understanding deeper.

b) Contiguity Principle

Learners can easily memorize and comprehend a content that provides pictures that complement the explanation it delivers. Therefore, to ensure the process of coordinating both explanation and pictures doesn't lead to cognitive overload, teacher may attach the pictures and corresponding words next to each other to be shown simultaneously.

c) Modality Principle

The complexity of graphics probably encumbers even more when they are presented rapidly one after another. Therefore, teacher needs to consider types of pictures and amount materials selected for the course carefully.

d) Redundancy Principle

Text which appears along with multimedia presentation increases the risk of overloading learners visual channel. Picture enters visual channel and the audio enters 
auditory channel. If text is also shown, it also most likely enters the visual channel. Thus, learners who lack of understanding the material may not be able to keep up with the explanation presented.

e) Coherence Principle

According to Dewey (1913), adding an interesting element into a boring lesson may not stimulate deep learning process. This statement shows that adding sounds to multimedia presentations probably overload the limited working memory capacity. As it influences the cognitive system, so the information and the sounds probably won't fit in limited cognitive resources (Clark \& Mayer, 2008). As a result, students can't concentrate on the explanation as their focus is distracted by the sounds.

f) Personalization Principle

In formal style of delivering information to leaners, teachers are supposed to explain the materials and learners are expected to comprehend them. However, not every learner can easily engage with this simplified scenario. Commonly, appropriate cognitive processes are important to understand the idea presented. Regarding this principle, Beck et al. (1996) argue that learners prefer the information to be expressed in conversational style.

g) Segmenting and Pre-Training Principles

Some parts of the materials can be more complex from the others. However, these parts take an important place to ensure the accuracy of learners' understanding. Therefore, the complex materials can be adjusted by dividing them into different segments to certify that learners manage to grasp the whole material.

Another way of minimizing the amount of crucial processing teacher discuss during of the presentation is pre-training. To avoid the overwhelmed cognitive system students may face, introducing characteristic of each part as cause-and-effect chain can help learners become familiar with the content area. In conclusion, learners can boost their essential processing by redistributing the portion of the lesson based on their capacity (Clark \& Mayer, 2008).

\section{Roles of Online Educator}

Abdous (2011) has cited Paulsen (1995) to define three roles of online educator: organizational, social and intellectual. Similar to this, Berge (1995) mentioned managerial, social, pedagogical and technical role. Another attempt to consider roles of online teachers was conducted by Goodyear (2001). 2000 participants in a practitioners' workshop have identified eight roles: process facilitator, adviser-counselor, assessor, 
Usemahu, Fernandita, Administering Classes in Virtual Learning Environment...

researcher, content facilitator, technologist, designer, manager-administrator. A later study conducted by Bawane and Spector (2009) has studied the roles to rate the prioritization and then defined eight roles in their research study. Based on these views, the following are several roles of online teacher that will be emphasized in this research:

a) Managerial

Managerial covers all organizational, administration and managerial tasks teachers must do. It is advised for educators to administer the online learning environment and organize the online learning resources for students' friendly access (Metz \& Bezuidenhout, 2018).

b) Pedagogical

This role covers both educator's interactive pedagogies and cognitive support for students.

c) Social

This role covers maintaining a positive and healthy space, helping, advising and providing support to studentson personal matters. Educator is also recommended to support student-faculty contact which set up presence in order to establish a supportive and friendly virtual environment. Both written and oral communication skills; showing positive online behaviour; providing a friendly learning environment are the competencies educator can manage from this role (Ní Shé, C. et al., 2019).

d) Technical

Technical role encompasses all aspects of technology in learning process including using technology pedagogically and administratively and supporting students' use of technology.

e) Assessor

Assessor role is responsibility for giving assessment and feedback and monitoring individual and group performance progress. Martin et al. (2019) mentioned that providing students prompt feedback and timely responses are helpful to support learners' success in thelearning process-

f) Facilitator

An online educator is expected to design a student-centered VLE and encourages students to actively participate and own the learning process which includes monitoring and guiding how students interact and cooperate within the group, promote interactivity, managing groupwork, advising and giving acceptable solution to the conflict in an amicable manner (Ní Shé, C. et al., 2019). Dunlap \& Lowenthal (2018) 
explained that Online teacher should be able to communicate their high expectations to students which will present accuracy and relevance. It is advised for educators to create serious job-related problem with rubrics as students' guidance, demonstrate responsibility and positive attitude, maintain learners' motivation, show leadership competencies and establish regulations (Ní Shé, C. et al., 2019).

g) Content Expert

According to Dunlap \& Lowenthal (2018), educator as a content expert should be able to provide accuracy. The competence includes content knowledge, library research skills, being in charge of updating knowledge, recommending students' learning resources, doing class observation, deciphering and combining the results of the research in the teaching and learning process (Ní Shé, C. et al., 2019).

h) Instructional Designer

In this role, the online teacher designs a suitable course for the VLE.

i) Researcher

Educator researches the course content and make sure it is updated.

j) Evaluator

Online educators evaluate their and students' performances, learning material \&content to boost improvements.

\section{Interaction in E-Learning}

\section{a. Types of Interaction}

There are five types of learners' interactions according to Chou et al. (2010): learner-learner interaction, learner-instructor interaction, learner-content interaction, learner-interface interaction, learner-self nteraction. According to Agal et al. (2010), elearning interactionscan be categorized into two different types: synchronous e-learning which allows teacher and students to interact at the same time, either through online conference or chatting room platform. Eventhough both parties are given opportunity to give immediate responses to each other, there is no flexibility of time provided; and Asynchronous E-learning which is much flexible in time compared to the previous one. Teacher and students can easily manage their time and communication for certain period until the task needs to be submitted.

\section{b. Types of Engagement in E-Learning}

According to Jered Borup (2013), engagement can be divide into three different types, as described below:

1) Student Engagement 
Usemahu, Fernandita, Administering Classes in Virtual Learning Environment...

Perry (2012) explained that emotions can be found in any educational activity the learners are in. Chapman (2003) also stated that learners may affectively engage when they emotionally react to learning tasks. Friedricks et al. (2004) added that both interaction students have with teachers and their peers can be perceived as psychological or affective engagement. In addition, Reeve (2012) discussed another emotional engagement in which the involvement of task-facilitating emotions that deal with students' interest and the avoidance of task-withdrawing emotions that possibly encumber them.

2) Teacher Engagement

Students' instructional needs is an important issue the teacher should address carefully. Effective personalized instruction may help teacher with the students needs and provide relevant strategies for the course. On the other hand, teacher also needs to ensure notonly to deliver instruction at specific time but also to manage their time to examine the works students submitted (Jered Borup, 2013).

3) Peer Engagement

Co-constructing new knowledge is a result of learners' collaboration which requires their commitment to work together. Teacher can provide collaborative learning experience for the learners where they can share their existing knowledge and compare each of their understanding toward certain materials. Even though it seems difficult, peers can encourage each other along with teacher support and design of activity (Jered Borup, 2013).

\section{METHOD}

This study used explanatory sequential mixed method which was started with quantitative analysis, followed with qualitative analysis and completed with the integration of both analysis (Creswell, 2012).

\section{Respondents}

The respondents were Students of Tarbiyah and Teacher Training Faculty of Antasari State Islamic University Batch 2017 who already experienced virtual learning environment. To be specific, there were a hundred and two students and three lecturers who took part in the study from twelve different majors. It is worth mentioning that the scientific background, major, gender, age, and other individual differences of the students were not considered in the present study.

\section{Instruments}

The researchers used two kinds of instrument: questionnaire and interview. The 
participants were given questionnaire using Google Forms consisting of 46 questions applying Likert scale based on the research questions and theoretical review. The data from quantitative process was analyzed statistically (See Nunan, 1992).

A list of questions was used as the instrument for the interview and conducted according to the result of questionnaire which consists of particular aspects the researcher considered need to be highlighted. It was aimed for the participants to elaborate their experience which might expand researchers' understanding of the VLE implementation.

\section{Validity and Reliability of the Data Collection Instruments}

Comparing rtable with the value of 0.195 with a significance level of $5 \%$ resulted in $\gamma \mathrm{pbi} \geq 0.195$. Thus, all items of the questions are considered valid. In terms of reliability, the Cronbach Alpha's score is higher than 0.600. Hence, it can be concluded that the questionnaire is reliable.

\section{Procedures}

In this study, students of Tarbiyah and Teacher Training faculty were contacted to voluntarily be part of this study via WhatsApp. The participants who intended to be studied were requested to fill out E- learning questionnaires. After analyzing the result, interviews were conducted on WhatsApp by employing open-ended questions that were specifically organized and classified employing both descriptive and explanatory methods. There were 14 students and 3 lecturers who participated in the interview process. Either texts or voice note, the participants are free to choose the mechanism of sending back their replies for their own comfort and ease. The students' responses to the questionnaires were analyzed by SPSS system Version 20 and the interview results were analyzed descriptively.

\section{Data Analysis}

The data from quantitative and qualitative were analyzed simultaneously. The qualitative process was constructed based on the quantitative data which was collected first. In addition, the data gathered in quantitative phase points out certain areas necessary to be highlighted in interview. As a result, one database builds on the other and the data collection can be expanded in order to collect more information.

\section{FINDINGS AND DISCUSSION}

\section{FINDINGS}

To begin with, the questionnaire survey was constructed from theoretical framework the researcher came up with which consists of four different scales: strongly 
Usemahu, Fernandita, Administering Classes in Virtual Learning Environment...

agree $=4$ points; agree $=3$ points; disagree $=2$ points; and strongly disagree $=1$ points for each question. Table I presents the result of the questionnaire survey.

According to Table I, the data covering 102 students' perception towards facilitation, principles, educators' roles and interaction in virtual learning environment reveals $19,6 \%$ are Highly Satisfied, $72,6 \%$ are Satisfied, 7,8\% are Unsatisfied and $0 \%$ is Highly Unsatisfied. The result of data analysis discovers the Mean score of 139, the Median score of 137, the Standard Deviation score of 15,5, the Minimum score of 102, and the Maximum score of 179. For deeper analysis of each four areas, the explanation will be elaborated in discussion.

Since this study drew its major point from the awareness to improve every aspect possible, it would involve interview whose questions were constructed by determining the data gathered from the questionnaire. In order to do that, the researchers managed to specify which aspects satisfy students the most and the least. To split the data into two major parts, the researchers would count satisfactory point for each category by dividing them into A (Highly Satisfied=2 points, Satisfied=1 point) and B (Unsatisfied $=1$ point, Highly Unsatisfied $=2$ points). The result of the facilitation will be demonstrated in Fig.1, the aspect of principle will be demonstrated in Fig.2, the aspect of educators' roles will be demonstrated in Fig.3, and the aspect of interactions will be demonstrated in figure 4.

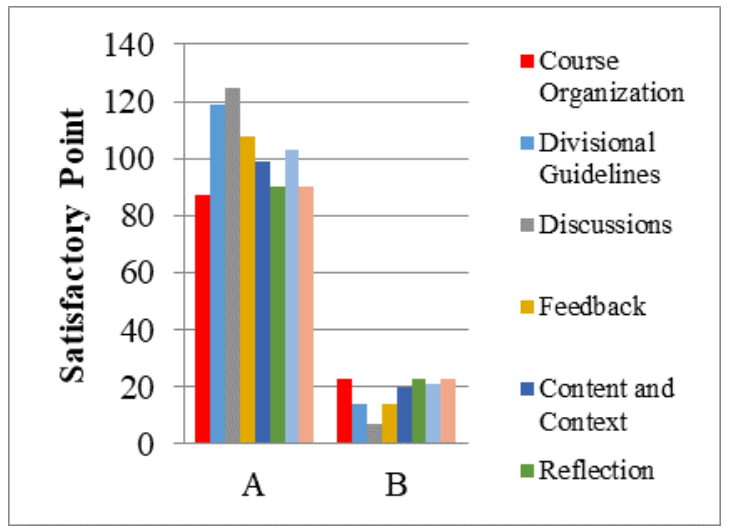

Figure 1. Satisfactory Point of Facilitation
Based on the data illustrated in figure 1 , it can be concluded that the students are most satisfied with the facilitation of discussion which reaches over 120 satisfactory point and least satisfied with the implementation of course organization. 


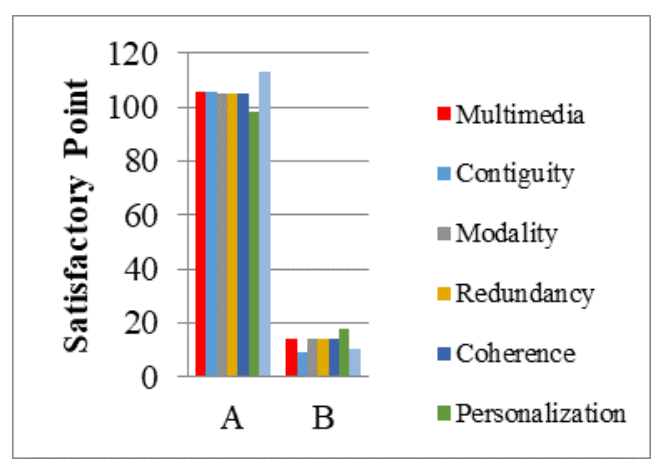

Figure 2. Satisfactory Point of Principle

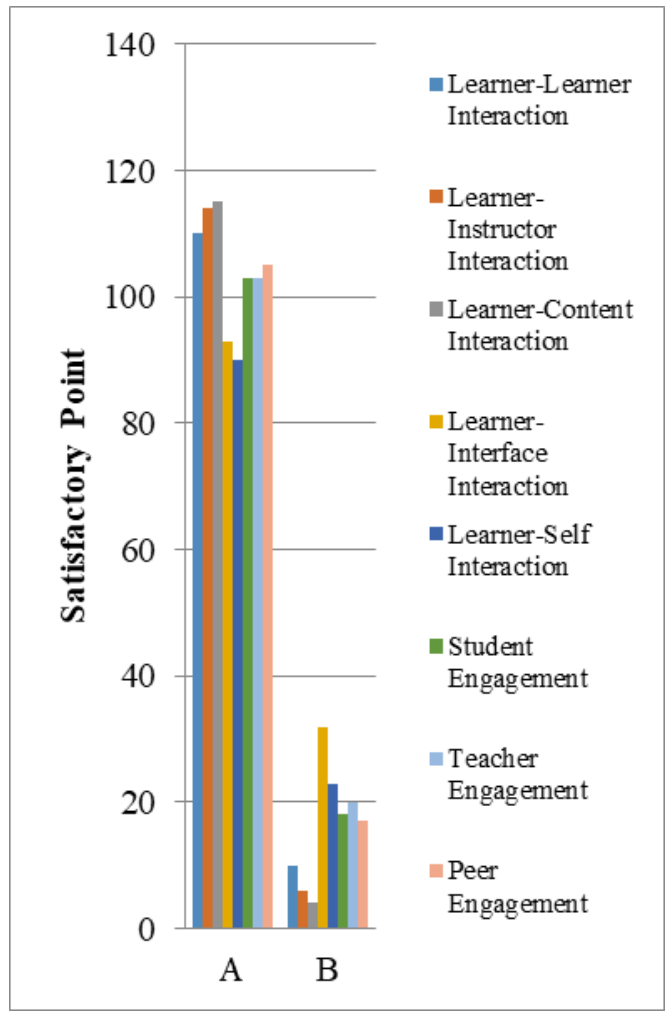

Figure 4. Satisfactory Point of Interaction

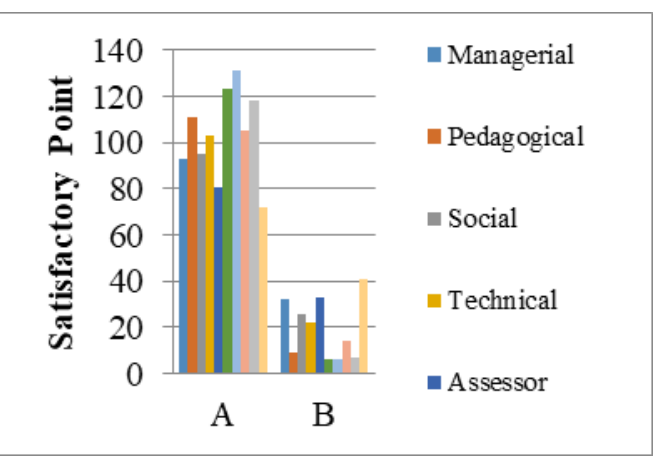

Figure 3. Satisfactory Point of Educator's Roles

Figure 2 shows that the students are most satisfied with the implementation of segmenting and pre-training and least satisfied with personalization. Based on the data presented in figure 3 , it can be concluded that the students are most satisfied with the educators' roles fulfillment of content expert and least satisfied with evaluator.

Meanwhile, in the aspect of interactions and engagement, it can be concluded that the students are most satisfied with the experience of learnercontent interaction and least satisfied with learner-interface interaction. To sum up, the researcher will construct an open-ended interview by employing specific areas students find most and least satisfying: the facilitation of discussions and course organization, the principle implementation of segmenting pre-training and personalization, educators' roles fulfillment of content expert as well as experience of learner-content interaction and learner-interface interaction. 
Usemahu, Fernandita, Administering Classes in Virtual Learning Environment...

Table I. Students Satisfaction towards Virtual Learning Environment

\begin{tabular}{|c|c|c|c|c|c|c|c|c|}
\hline & & & & 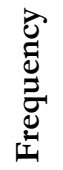 & 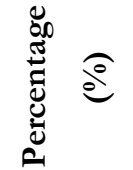 & 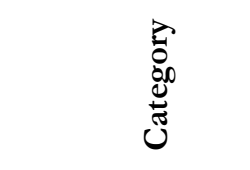 & & \\
\hline \multirow{5}{*}{$\begin{array}{l}\text { Students' } \\
\text { E-Learning } \\
\text { Satisfactory }\end{array}$} & 151 & - & 184 & 20 & $19,6 \%$ & Strongly agree & Mean & 139 \\
\hline & 116 & - & 150 & 74 & $72,6 \%$ & Agree & Median & 137 \\
\hline & 81 & - & 115 & 8 & $7,8 \%$ & Disagree & Std. Deviation & 15,5 \\
\hline & 46 & - & 80 & 0 & 0 & Strongly disagree & Minimum & 102 \\
\hline & & & & & & & Maximum & 179 \\
\hline
\end{tabular}

Table II. Interview Result

\begin{tabular}{|c|c|c|c|c|}
\hline Aspect & \multicolumn{2}{|c|}{ Principle } & \multicolumn{2}{|c|}{ Facilitation } \\
\hline Theme & $\begin{array}{c}\text { Segmenting and Pre- } \\
\text { Training }\end{array}$ & Personalization & Discussions & $\begin{array}{c}\text { Course } \\
\text { Organization }\end{array}$ \\
\hline \multirow[t]{5}{*}{ Data } & $\begin{array}{l}\text { Considering the } \\
\text { material's complexity } \\
(\mathrm{x} 9) \text {. }\end{array}$ & $\begin{array}{l}\text { Explaining in } \\
\text { detail (x8). }\end{array}$ & Giving reward (x6). & $\begin{array}{l}\text { Paying attention to } \\
\text { students' progress } \\
\text { (x6). }\end{array}$ \\
\hline & $\begin{array}{l}\text { Focusing on students' } \\
\text { ability (x5). }\end{array}$ & $\begin{array}{l}\text { Providing } \\
\text { example }(x 4)\end{array}$ & $\begin{array}{l}\text { Conducting question } \\
\text { and answer sessions } \\
(\mathrm{x} 5) \text {. }\end{array}$ & $\begin{array}{l}\text { Scheduling the } \\
\text { course activities } \\
\text { (x5). }\end{array}$ \\
\hline & $\begin{array}{l}\text { Discussing the } \\
\text { material proportion } \\
\text { with the students }(\mathrm{x} 2) \text {. }\end{array}$ & $\begin{array}{l}\text { Taking students' } \\
\text { learning pace } \\
\text { into account } \\
\text { (x3). }\end{array}$ & $\begin{array}{l}\text { Establishing friendly } \\
\text { atmosphere (x3). }\end{array}$ & $\begin{array}{l}\text { Arranging the } \\
\text { materials }(\mathrm{x} 3) \text {. }\end{array}$ \\
\hline & $\begin{array}{l}\text { Be aware of the } \\
\text { limitation of } \\
\text { distance learning } \\
(\mathrm{x} 1) \text {. }\end{array}$ & $\begin{array}{l}\text { Simplifying } \\
\text { complicated } \\
\text { material (x2). }\end{array}$ & $\begin{array}{l}\text { Sharing the materials in } \\
\text { advance (x2). }\end{array}$ & $\begin{array}{l}\text { Considering } \\
\text { students network } \\
\text { access }(\mathrm{x} 2) \text {. }\end{array}$ \\
\hline & - & - & $\begin{array}{l}\text { Utilizing interactive } \\
\text { platform (x1). }\end{array}$ & $\begin{array}{l}\text { Conducting weekly } \\
\text { meeting (x1). }\end{array}$ \\
\hline Aspect & \multicolumn{2}{|c|}{ Role } & \multicolumn{2}{|c|}{ Interactions } \\
\hline Theme & Content Expert & Evaluator & $\begin{array}{l}\text { Learner-Interface } \\
\text { Interaction }\end{array}$ & $\begin{array}{l}\text { Learner-Content } \\
\text { Interaction }\end{array}$ \\
\hline \multirow[t]{3}{*}{ Data } & $\begin{array}{l}\text { Capable of delivering } \\
\text { understandable } \\
\text { explanation }(x 7)\end{array}$ & $\begin{array}{l}\text { Including } \\
\text { constructive } \\
\text { comments }(x 7) \text {. }\end{array}$ & $\begin{array}{l}\text { Considering platform's } \\
\text { features (x5). }\end{array}$ & $\begin{array}{l}\text { Putting the course } \\
\text { content into group } \\
\text { discussions (x8). }\end{array}$ \\
\hline & $\begin{array}{l}\text { Providing facts in the } \\
\text { field }(x 4) .\end{array}$ & $\begin{array}{l}\text { Finishing the } \\
\text { evaluation as } \\
\text { soon as possible } \\
(\mathrm{x} 4) \text {. }\end{array}$ & $\begin{array}{l}\text { Selecting commonly } \\
\text { used platforms (x5). }\end{array}$ & $\begin{array}{l}\text { Offering particular } \\
\text { project to put the } \\
\text { material into } \\
\text { practice }(x 4) \text {. }\end{array}$ \\
\hline & $\begin{array}{l}\text { Discussing the } \\
\text { material proportion } \\
\text { with the students }(\mathrm{x} 2) \text {. }\end{array}$ & $\begin{array}{l}\text { Explaining } \\
\text { which aspects } \\
\text { students struggle }\end{array}$ & $\begin{array}{l}\text { Taking the accessibility } \\
\text { into accounts }(x 5) \text {. }\end{array}$ & $\begin{array}{l}\text { Conducting } \\
\text { engaging activities } \\
\text { (x3). }\end{array}$ \\
\hline
\end{tabular}


Volume 7, Number 01, June 2021

\begin{tabular}{|l|l|l|l|l|}
\hline & with (x3). & & \\
\cline { 2 - 5 } & $\begin{array}{l}\text { Dividing the } \\
\text { materials into } \\
\text { several parts (x3). }\end{array}$ & $\begin{array}{l}\text { Evaluating each } \\
\text { student's work } \\
\text { fairly (x2). }\end{array}$ & $\begin{array}{l}\text { Asking for students' } \\
\text { suggestions (x2). }\end{array}$ & $\begin{array}{l}\text { Providing individual } \\
\text { assignments (x2). }\end{array}$ \\
\cline { 2 - 5 } & $\begin{array}{l}\text { Possessing deep } \\
\text { understanding by } \\
\text { answering students' } \\
\text { question (x2). }\end{array}$ & $\begin{array}{l}\text { Utilizing } \\
\text { platform with } \\
\text { automatic } \\
\text { evaluation } \\
\text { feature (x1). }\end{array}$ & - & - \\
\hline
\end{tabular}

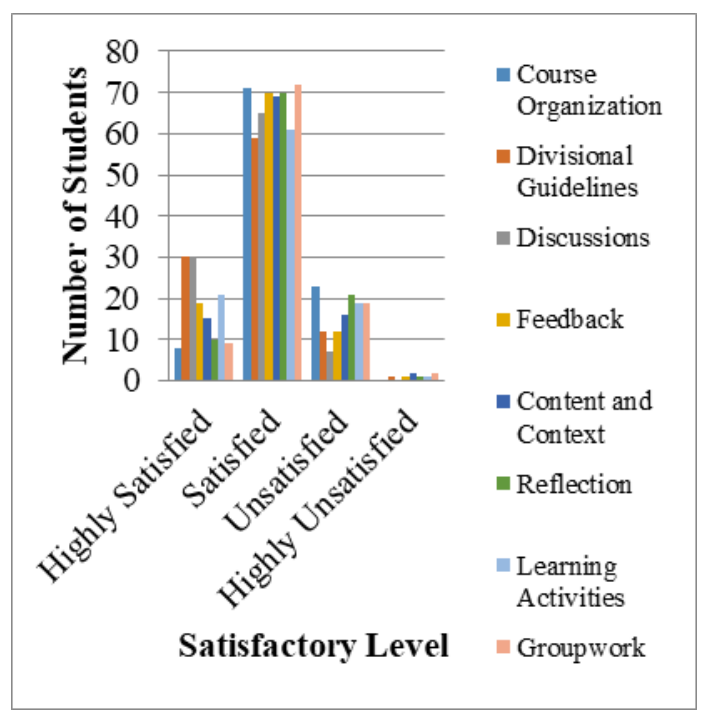

Generally, many students of the study have been satisfied towards the facilitation of VLE. Two of them state the satisfaction in the following:

- Lecturer provides a particular material, such as in writing course. Usually, after explaining the material, the students will be instructed to put the knowledge obtained into practice. For example, we are learning about paraphrasing; therefore, we are given short article to be paraphrased immediately. Right after we finished the task, it will be sent to and be evaluated by the lecturer.

-The difficulty and our capability are taken into account so that we are able to consume it in our own way.

Fig. 5 E-Learning Facilitation Satisfactory

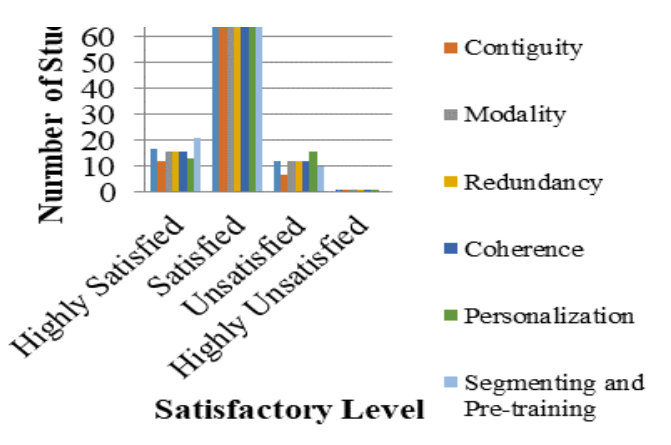

Specifically, there are 30 students are highly satisfied and 65 students are satisfied in the 
Usemahu, Fernandita, Administering Classes in Virtual Learning Environment...

implementation of divisional guidelines and discussions. However, 23 students believe that the course organization does not put them at ease to track down their steps yet. On this aspect, one student stated:

-(The lecturer) utilized similar methods and strategies in every meeting.

Below is a lecturer's view regarding difficulties to bring forth a consistent e-learning design:

-Since (the learning) is conducted remotely, obviously (the consistency of) the learning will eventually decrease.

Fig. 6 E-Learning Principle Implementation Satisfactory

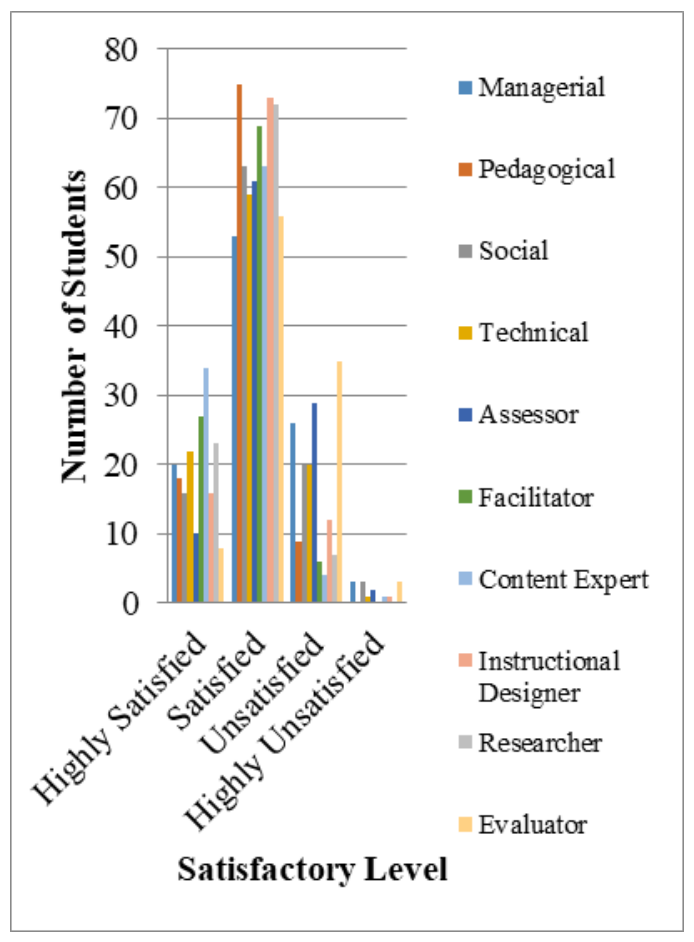

For the principles of designing classroom in digital platform, fewer unsatisfied students were discovered compared to the previous aspect. To be precise, 21 students are highly satisfied and 71 students are satisfied with the proportion of materials. One participant admitted that materials adjustment has lifted a burden off his shoulders by saying that:

-As the class duration is limited, too complex materials may give me a headache.

Another opinion expressed from the point of view of a lecturer, as stated below:

-I take into consideration each (materials') part that will become students' assignments, however, I still pay attention to their capability as students.

In contrast, sixteen students indicate that materials delivery can be adjusted into more comprehensible and engaging explanation and one students is highly unsatisfied. 
Fig. 7 E-Learning Educators' Roles Fulfillment Satisfactory

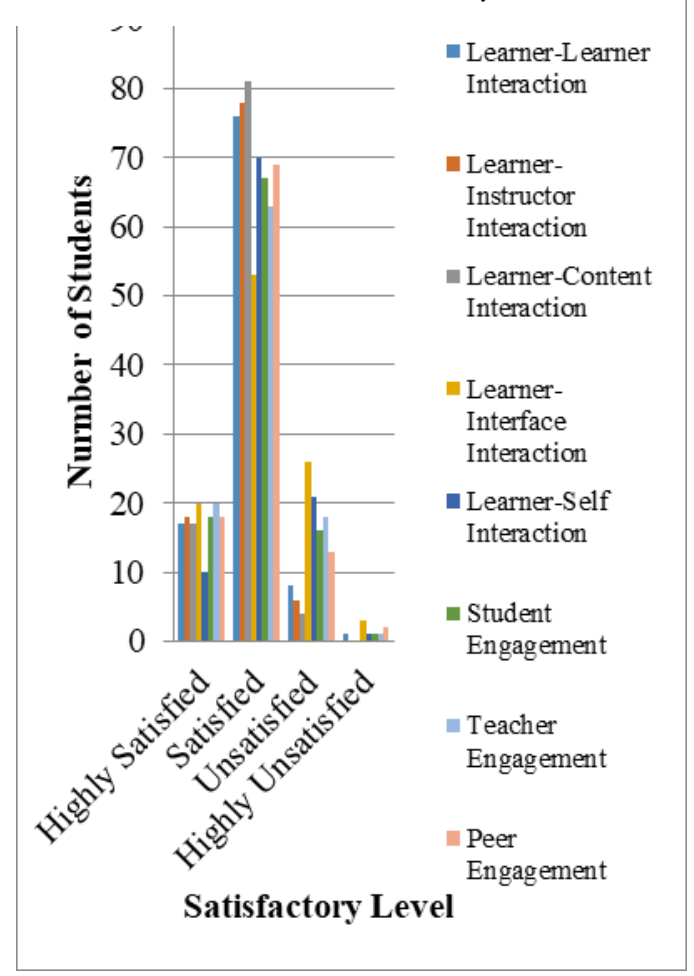

For lecturers' roles, fig. 7 presents students' opinion towards certain essential responsibilities of online learning implementation. As a content expert, 34 students are highly satisfied and 63 students are satisfied with lecturers' attempts to provide understandable explanation of the course subject. On the other hand, 35 students indicate the evaluation of their actions and the course content is an issue lecturers need to address and 3 students are highly unsatisfied. The following expression is an example of the role of evaluator as student's subject of concern:

-The lecturer does not give the right answer, but they show us which questions we got wrong.

One participant points out the importance of sparing students' feelings in evaluation by saying that:

-(The lecturer) should praise (students' effort) and highlight errors in their explanation without looking down at the students' presentation (of the material).

For the interactions during online course, most of the students are already satisfied. Furthermore, seventeen students are highly satisfied and 81 students are satisfied when it comes to management of perceptual contact between students and the content materials. 
Usemahu, Fernandita, Administering Classes in Virtual Learning Environment...

Even so, learner-interface interaction hit the highest point of dissatisfaction. 26 students admit that they struggle with learning platform lecturer provided and 3 students are highly unsatisfied. One of the students share his/her experience below:

-Poor network becomes the barrier, therefore, the platform use cannot be optimized.

-Sometimes, course should be cancelled due to bad weather, blurry image, or unclear audio.

\section{DISCUSSIONS}

\section{Facilitations}

The data presents that students are most satisfied with the implementation of class discussion. In the interview, students claimed that the lecturers provide them questions and answers session and reward active students during the class. Another supporting factor in the successful class discussions is the lecturers are able to create warm and friendly atmosphere. Lecturers start the class by greeting students and sometimes use humorous analogies in teaching. Selecting online learning platforms is considered thoughtful since most of the time lecturers involve students in the decision making. Low bandwidth applications are mostly preferable to allow the materials accessible for all students.

On the flip side, the data shows that students are least satisfied with the class organization. 23 students believe that the course organization does not put them at ease to track down their steps yet. Lecturers, particularly in general subjects, use similar methods and learning activities. These suggest that lecturers need to reconsider the course structure to overcome the implementation barriers.

\section{Principles}

In principles implementation, the students' responses are a lot more positive compared to facilitation. Proportion of material was applied well in the limited class duration. Students' capability and the workload of students' assignments have already been taken into account.

In contrast, sixteen students show their dissatisfaction and one student is highly unsatisfied in personalization indicating that materials delivery can be adjusted into more comprehensible and engaging explanation. This shows that the lecturer should modify their styles to introduce materials more effectively.

\section{Educators' Roles}

In this section, the high number of satisfaction for role of content expert demonstrates that lecturers have provided clarity in delivering the course subject. However, that 35 students are dissatisfied and 3 are highly dissatisfied for educators' role of evaluator means there's an issue to address. More in the interviews mentioned that some lecturers are lacking in 
providing them meaningful feedback. Similar to the finding of the previous study conducted by his indicates that lecturers should gain a better foothold on the foundation of students' evaluation in VLE to support their ongoing growth.

\section{Interactions}

Most students are already satisfied with the interaction during online courses, especially for learner-content interaction. The material given will immediately be put into practice through engaging activities, projects and individual assignments. Those lecturers are available in office hours to contact supports the students understanding of the materials and the assignments.

The only struggle in interactions is students' limited internet access. Despite the online platform has been carefully selected to have broadband as low as possible, many who live in remote areas often skip virtual meeting because of the poor network. Another point worth considering is no matter where they live, not all students have unlimited internet access. Those who depend on daily/weekly mobile data are most likely not to attend the whole session of the virtual meeting. To cope with this problem, the lecturers utilize Google Drive to deliver materials through meeting recording for students to download anytime.

\section{E. CONCLUSION}

In this investigation, the results indicate that despite students' limited access to the internet, most lecturers attempt to provide facilities to all students. However, in some departments, various learning activities, class organization and feedback still need to be improved. The lecturers generally execute the principles of virtual learning environment except for the role of evaluator which lecturers need to pay attention better. The students mostly believe that lecturers are aware of their roles and overall their interactions were managed well. Taken together, these results suggest lecturers be well-prepared for varieties of learning activities and the management of class organization. The other findings of this study have identified are the lecturers still lack the role of evaluator and students were given minimum feedback. Thus, it suggests that lecturers should take the assessment design into account.

Though the results add to the rapidly expanding field of class administration in VLE, we suggest that the data would have been more accurate if more sample of lecturers were involved. The results are expected to contribute to building better teaching and learning qualities in quarantine policies. Finally, further researches related in this field would be of great help in exploring the best practices of VLE in Indonesia. 
Usemahu, Fernandita, Administering Classes in Virtual Learning Environment...

\section{REFERENCES}

Abdous, M. (2011). A Process-Oriented Framework for Acquiring Online Teaching Competencies. Journal of Computing in Higher Education, 23(1), 60-77. Retrieved from https://doi.org/10.1007/s12528-010-9040-5

Agal, S., Dave K. K., \& Devija, P. (2010). Can E-Learning Replace the Traditional Classroom? A Case Study at a Private College in Udaipur. Educational Reforms: Insights and Analysis, 2 (1), 173-178.

Atmojo, Arief \& Nugroho, Arif. (2020). TEFL Classes Must Go Online! Teaching Activities and Challenges during COVID-19 Pandemic in Indonesia. Register Journal. 13(1). 49-76. Retrieved from https://doi.org/10.18326/rgt.v13i1.49-76

Baran, E., Correia, A.-P., \& Thompson, A. (2011). Transforming Online Teaching Practice: Critical Analysis of the Literature on the Roles and Competencies of Online Teachers. Distance Education, 421-439. Retrieved from https://doi.org/10.1080/01587919.2011.610293

Bawane, J., \& Spector, J. M. (2009). Prioritization of Online Instructor Roles: Implications for Competency-Based Teacher Education Programs. Distance Education, 30(3), 383-397. Retrieved from https://doi.org/10.1080/01587910903236536

Beck, I., McKeown, M.G., Sandora, C., Kucan, L., \& Worthy, J. (1996). Questioning the Author: A Year-Long Classroom Implementation to Engage Students in Text. Elementary School Journal, 96, 385-414. Retrieved from https://doi.org/10.1086/461835

Berge, Z. L. (2008). Changing Instructor's Roles In Virtual Worlds. Quarterly Review of Distance Education, 9(4), 407-414. Retrieved from https://doi.org/10.1080/01587919.2011.610293

Borup, J., \& Evmenova, A. (2019). The Effectiveness of Professional Development in Overcoming Obstacles to Effective Online Instruction in a College of Education. Online Learning, 23(2). Retrieved from https://doi.org/10.24059/olj.v23i2.1468

Chapman, E. (2003). Alternative Approaches to Assessing Student Engagement Rates. Practical Assessment, Research and Evaluation, 8(8), Article 13. Retrieved from https://doi.org/10.7275/3e6e-8353

Chickering, A., \& Gamson, Z. (1987). Seven Principles for Good Practice in Undergraduate Education. AAHE Bulletin, 3-7. Retrieved from https://files-eric-edgov.dcu.idm.oclc.org/fulltext/ED282491.pdf

Chou, Chien, Peng, Hsinyi, \& Chang, Chun-Yu. (2010). The Technical Framework of Interactive Functions for Course-Management Systems: Students' Perceptions, Uses, and Evaluations. Computers \& Education, 55(3), 1004-1017. Retrieved from https://doi.org/10.1016/j.compedu.2010.04.011

Coker, H. (2018). Purpose, Pedagogy and Philosophy: "Being" an Online Lecturer. The 
International Review of Research in Open and Distributed Learning, 19(5). Retrieved from https://doi.org/10.19173/irrodl.v19i5.3312

Coppola, N. W., Hiltz, S. R., \& Rotter, N. G. (2002). Becoming a Virtual Professor: Pedagogical Roles and Asynchronous Learning Networks. Journal of Management Information Systems, 18(4), 169-189. Retrieved from https://doi.org/10.1080/07421222.2002.11045703

Corfman, T., \& Beck, D. (2019). Case Study of Creativity in Asynchronous Online Discussions. International Journal of Educational Technology in Higher Education, 16(1), 22. Retrieved from https://doi.org/10.1186/s41239-019-0150-5

Destianingsih, Arita \& Satria, Ari. (2020). Investigating Students' Needs for Effective English Online Learning During COVID-19 for Polbeng Students. ELT Lectura: Studies and Perspectives in English Language Teaching. 7 (2). 147-153. Retrieved from https://journal.unilak.ac.id/

Dewey, J. (1913). Interest and Effort in Education. Cambridge, MA: Houghton Mifflin.

Dunlap, J. C., \& Lowenthal, P. R. (2018). Online Educators' Recommendations for Teaching Online: Crowdsourcing in Action. Open Praxis, 10(1), 79-89. Retrieved from https://doi.org/10.5944/openpraxis.10.1.721

Gómez-Rey, P., Barbera, E., \& Fernández-Navarro, F. (2018). Students’ Perceptions About Online Teaching Fffectiveness: A Bottom-Up Approach for Identifying Online Instructors' Roles. Australasian Journal of Educational Technology, 34(1). Retrieved from https://doi.org/10.14742/ajet.3437

Goodyear, P., Salmon, G., Spector, J. M., Steeples, C., \& Tickner, S. (2001). Competences for Online Teaching: A Special Report. Educational Technology Research and Development, 49(1), 65-72. Retrieved from https://doi.org/10.1007/BF02504508

Hamid, R., Sentriyo, I., \& Hasan, Sakka. (2020). Online Learning and Its Problem in the COVID-19 Emergency Period. Jurnal Prima Edukasia. 8 (1).86-95. Retrieved from https://journal.uny.ac.id/index.php

Martin, F., Ritzhaupt, A., Kumar, S., \& Budhrani, K. (2019). Award-Winning Faculty Online Teaching Practices: Course Design, Assessment and Evaluation, and Facilitation. The Internet and Higher Education, 42, 34-43. Retrieved from https://doi.org/10.1016/j.iheduc.2019.04.001

Meyer, K. A., \& McNeal, L. (2011). How Online Faculty Improve Student Learning Productivity. Online Learning, 15(3). Retrieved from https://doi.org/10.24059/olj.v15i3.169

Meyer, K. A. (2013). An Analysis of the Research on Faculty Development for Online Teaching and Identification of New Directions. Online Learning, 17(4). Retrieved from https://doi.org/10.24059/olj.v17i4.320 
Usemahu, Fernandita, Administering Classes in Virtual Learning Environment...

Ní Shé, C., Farrell, O., Brunton, J., Costello, E., Donlon, E., Trevaskis, S., Eccles, S. (2019) Teaching Online is Different: Critical Perspectives from The Literature. Dublin: Dublin City University. Retrieved from https://doi.org/10.5281/zenodo.3479402

Paulsen, M. (1995). The Online Report on Pedagogical Techniques for Computer-Mediated Communication. Oslo: NKI [Online]. Retrieved from https://textarchive.ru/c-2291217pall.html

Peacock, S., \& Cowan, J. (2019). Promoting a Sense of Belonging in Online Learning

Communities of Inquiry. Online Learning, 23(2). Retrieved from https://doi.org/10.24059/olj.v23i2.1488

Perry, D. L. (2012). What Makes Learning Fun?: Principles for The Design of Intrinsically Motivating Museum Exbibits.California: AltaMira Press.

Shanghai American School. (2020). SAS Distance Learning Plan. SAS Learning Community [Online]. Retrieved from https://www.saschina.org/uploaded/SAS Distance Learning_Plan.pdf

Shattuck, J., Dubins, B., \& Zilderman. (2011). Maryland Online's Inter-Institutional Project to Train Higher Education Adjunct Faculty to Teach Online. The International Review of Research in Open and Distributed Learning, 12(2). Retrieved from http://www.irrodl.org/index.php/irrodl/article/view/933

Trammell, B. A., \& LaForge, C. (2017). Common Challenges for Instructors in Large Online Courses: Strategies to Mitigate Student and Instructor Frustration. Journal of Educators Online, 14(1), 11. Retrieved from https://eric.ed.gov/?id=EJ1133615 